\title{
Customer Service as a Tool for an Effective Customer Retention in Camtel South-West Region of Cameroon: An Analysis from Customer's View
}

\author{
Dr. Nwahanye Emmanuel* \\ Senior Lecturer, University of Buea Cameroon
}

*Corresponding Authors: Dr. Nwahanye Emmanuel, Senior Lecturer, University of Buea Cameroon

\begin{abstract}
Over the years, Camtel the state-owned corporation which is the pioneer in the country has recorded no significant increase in its customer base when compared with the other telecommunications companies like MTN Cameroon, Orange and Nexttelwhich are making massive moves towards attracting and maintaining customers. The main objective of this paper is to assess the effect of customer service on customer retention from customers' perspective with the case study Camtel South-West which is experiencing a severe drop of its turnover. Data were collected through questionnaires administered to 90 customers of Camtel South-West Region. Data were analyzed using the Principal Component Analysis and an OLS regression.Findings show that the overall customer service is a significant tool for customer retention. In addition communication management and staff attitudes are the constructs of customer service that are significantly and positively correlated to customer retention. Complaints management and promises management are not significant. The study therefore recommends that CamtelSouth-West management should improve its customer service, emphasizing on building a good customer relationship management, developing information and communication systems, and training its staff to be responsiveto increase loyalty and retention.
\end{abstract}

Keywords: Customer service; Customer retention; Camtel South-West Region

\section{INTRODUCTION}

In the 21 st century, business organisations are becoming increasingly customer oriented. In that perspective, customer retention has become a key relationship marketing concept related to developing and preserving a long lasting relationship with customers (Boora, 2017). In the telecommunication industry, the power has clearly shifted to the consumers. Never before have the barriers to switching telecommunication providers been so low. While loyalty tends to be high among older consumers, younger consumers are accustomed to continuously shopping around for the best offers. According to global consulting firm, Accenture, the steady increase in customer churn rates is being driven by several factors, including equipment envy, flexible pricing plans, customer service, network performance, and number portability. Customer churn among cable and telecommunications companies is projected to cost organisations up to $\$ 10$ billion annually worldwide.

So, faced with this competitive landscape, several tactics are being employed to retain customers in an industry where differentiation is extremely difficult to maintain. One of the tactic is the emphasis on customer service, one of the major issue that influences businesses in the $21^{\text {st }}$ century. Customer service management has played strategic roles in the improving, managing, retaining and developing customer's loyalty in today's competitive environment (Oluseyeet.al., 2014). It globally appears as a potential and effective tool that telecommunication industry can use to gain a strategic advantage and survive in today's ever-increasing telecommunication competitive environment. For Hossain et.al. (2017), as the telecommunication system has turned into the enormously competitive owing the liberalization of communication system to gear up the communication process, effort should be made by the telecommunication companies to learn the consumer needs, and serve that needs smarter than competition in order to attaining customer loyalty and maintaining the success in the competitive telecommunication business.

In Cameroon telecommunication industry, while Mtn Cameroon, Orange and Nextel are making massive moves towards attracting and maintaining customers through an efficient customer 
relationship management and increased service quality, the state-owned corporation Camtel which is the pioneer in the country has over the years recorded no significant increase in its customer base when compared with the former. Ironically, Camtel customers keep on switching from this sector to enjoy the quality services offered by its competitors. In the case of Camtel South-West, this is illustrated by a drastic decrease of its sales revenues from 1,377,044,457 CFAF in 2013 to 244,240,941 CFAF in 2017. With this trend in addition to the potential effects of the ongoing crisis in the region, if nothing is done Camtel South-West will loss almost all its customers except the public administration services constraint to use Camtel services.

In view of the above, there is dire need to conduct a study on customer retention in Camtel SouthWest, because if retention is not managed, customer's loyalty may be lost. In addition, it is important to consider the observations of Fluss (2010) concerning the attitudes of competitors and the annual customer attrition in some industries and more particularly in the telecommunication industry. $\mathrm{He}$ noted that competitors are always on the lookout to steal customers through better deals. He observed that annual customer attrition rates range from $7 \%$ in industries that have high exit barriers such as banking and insurance, to almost $40 \%$ in the mobile phone industry (Molapo\&Mukwada, 2011). It therefore appears that customers in the telecommunication industry keep on switching network providers for better deals.

Customer retention that has long been consideredan important element in achieving competitive advantage for businesses, is an approach in which organisations emphasize their exertions on current customers with the aim to carry on business with them (Mostertet.al., 2009). It is defined as the objective of marketing that bars customers from joining the competition (Ramakrishnan, 2006). The increasingly turbulent economic environment has brought this again to the forefront for many organisations (McCrory, 2013). In fact, the contemporary advancement of commerce and emerging of markets has led to radical economical fluctuations and inflamed fierce competition (Narteh, 2013). As a result, the consumer today has a multitude of alternatives to exceed his expectations when making a purchasing decision, whereas, rivalry has reached its climax (Leal \& Pereira, 2003). Consequently, given the assumption that loyal customers are a vital ingredient of a sustainable business operation, retaining these customers is no doubt an interactive catalyst that will systematically influence the long-term success of any enterprise in today's service-driven economy. In this regard, customer retention strategy signifies the vaccine that must be utilized by enterprises to diminish the risk of substitutes (Komunda\&Osarenkhoe, 2012).

Globally, businesses rely on customers for their survival. The pressures of competition dictate that customers must be at the centre of everything that a business does. Value is relatively easy to achieve, but lifetime loyalty can only be achieved when a customer is given a good service and wants to come back again. Customer service therefore appears as an important tool in retaining customers. It is also the view retained in this study. Customers have come to expect certain levels of customer service that they will receive before, during and after the sale of a product or a service. The extent of these expectations will vary with the nature of the product or the service. Customer service relates to issues such as such attitudes, the premises and the products (or services). Customer service relates very much to the use of communication skills (an employee of a business must be able to tell the customer about the product or service and be able to deal with complaints.

Studies on customers' service, customer loyalty and customers' retention are no longer a new topic in the field of customer relationship management practice and philosophies (Lucas, 2005). However, after a thorough search, limited studies have been carried out regarding the effectiveness of customer service in the retention of customers in developing economy such as Cameroon and more precisely in a public company that had monopoly in the past and today is almost the last in the market despite huge investments. In addition, service quality in telecommunication sector have been the main focus in research while customer service as well as its influence on customer retention has been given limited attention. This research therefore seeks to examine the effect on customer service on customer retention. This research is significant to Camtel because, it will allow to identify the parameters of Camtel's customer service that potentially contribute to the retention of the existing customers.

The rest of the article reviews the literature, outlines the methodology used, presents and discusses the findings, and concludes. 


\section{LITERATURE REVIEW}

\subsection{Understanding what Customer Service is}

Customer service refers to the service provided in support of the company's products and promises made (Zeithaml\&Bitner, 2003) and where all business processes and individuals are focused on the customer (Coelho \&Henseler, 2012). Today's customer service goes far beyond the traditional telephone support agent. It's available via email, web, text message, and social media. Many companies also provide self-service support, so customers can find their own answers at any time day or night. Customer support is more than just providing answers; it's an important part of the promise your brand makes to its customers (Winer, 2001).

The main objective of customer service is customer satisfaction. Therefore an effective customer service is the one that provide satisfaction to customers. A satisfied customer does not mean someone who does not have complaints, he is simply someone who is genuinely happy with the service, the product and the whole experience of dealing with the organisation. The aspects that can be observed in assessing the effectiveness of an organisation customer service are its staff (in terms of general appearance, mood and expression, attitude, product knowledge, training, communication abilities, etc.), the premises (special offers, etc.), the quality and the value of the products or services.

\subsection{Customer Retention}

Ramakrishnan (2006) defines customer retention as the marketing goal of preventing customers from going to the competitor. Menon and O'Connor (2007) on their part defined customer retention as holding and maintaining customers to maximize customer life time value by creating effective relationship with the firm. To them, there are different variables that can influence companies' customer retention such as communication, customer information, empowerment, customization, loyalty programs, ethical behavior and technology of the firm. Customer retention is the way in which organisations focus their efforts on existing customers in an effort to continue doing business with them (Mostertet.al., 2009). It is defined by Hau and Ngo (2012), as a process or set of steps taken to reduce customer churn rate or defection. It refers to the ability of an industry or business to retain its customers over some specific period to gain profitability and long-term sustainability in the market (Banik\& Sinha, 2020). Customer retention usually exists when the service provider is able to fulfill the customer expectation and further maintain it in the long-term relationships in order to guarantee long-term buying decisions (Chee, 2019; Otaigbe, 2018; Preikschas et.al., 2017).

In the light of these definitions, this study adopted customer retention as a process whereby an organisation does every things possible to restrict its customers from going to competitors.

\subsection{Customer Service and Customer Retention}

Theoretically, companies with effective customer service have many benefits. Firstly, it is always cheaper to retain an existing customer than to attract a new. Secondly, it provides higher value to the customers. It is an integrated approach to marketing, service and quality and thus, helps the companies in gaining a competitive advantage over the others. Another advantage of customer service is that long term customers may do referrals and viral promotion for the companies. Moreover, with time, because of good customer relationships, customers tend to increase their purchases, and there is less need for the companies to offer certain price promotion to the retained customers (Parasuramanet.al., 1988).

Empirically, some studies were conducted in linking customer service to customer retention. Majority of these studies are oriented towards service quality. Banik and Sinha (2020) conducted a systematic review of 50 research papers published across reference peer reviewed journals during 2001-2019 in telecom sector, in order to explore the factors affecting towards the customer retention from the customers prospective in line with the experience of mobile connections to India. They found $64 \mathrm{sub}$ factors affecting retention in telecom sector and then categorized these factors into significant factors such as service, support, brand, network coverage, pricing, and customer relation and regulation impact. Chee (2019) proposed a conceptual framework showing the relationship between service quality, customer satisfaction, customer loyalty, and customer retention in Malaysia Telecom industry. It appears from the framework that service quality which include customer service and other variable indirectly affect customer retention through it effect on customer satisfaction and the effect of customer satisfaction on customer loyalty. 
Rizomyliotiset.al. (2018) developed and tested a multi-level model on the antecedents of customer loyalty using empirical data from the UAE mobile telecommunication sector. Using data from 374 subscribers collected via a survey, they found that perceived service quality, customer satisfaction and customer trust have a positive and direct effect on customer loyalty. By cons, perceived service value does not significantly affect customer loyalty. Hafez and Akther (2017) investigated the determinants of customer loyalty in telecom industry in Bangladesh and found from a sample of 200 telecom customers that service quality, customer satisfaction, trust, and corporate image have certain degree of relationship with customer loyalty but switching cost did not prove to have any significant relationship with customer loyalty. Boora (2017) examined the influence of perceived quality of service on customer retention in the perspective of mobile telecom services in the state of Haryana. The results reveal that the perceived quality of service in the context of mobile telecommunication services delivered a positive influence on customer retention.

Izogo (2016) examined how firms can influence customer loyalty through customer commitment by leveraging two constructs of service quality: service assurance and service reliability. Using data from 138 experienced users of mobile phone services in one of the big cities in the South-eastern part of Nigeria through a survey questionnaire, he found that service reliability is a direct predictor of customer loyalty while service assurance is not. Affective commitment partially mediates the relationship between service reliability and customer loyalty. In contrast, the mediating effects of affective and continuance commitment on the relationship between service assurance and customer loyalty were positive but insignificant.Dubey and Srivastava (2016) investigated the impact of service quality on customer relationship management and customer loyalty in the Indian telecom sector using SERVQUAL model of Parasuraman et.al. (1988) and showed that service quality has significant and positive impact on customer loyalty.Ngo and Nguyen (2016) developed and empirically tested the interrelationships between service quality, customer satisfaction, and customer loyalty in a retail banking context. The analysis reveals that service quality and customer satisfaction are important antecedents of customer loyalty and customer satisfaction mediates the effects of service quality on customer loyalty.

Dambush (2014) assessed the role of customer relationship marketing on customer retention in Ethiopian Insurance Corporation (Mekelle Branch) using cross sectional survey design and found that relationship marketing dimensions such empathy, trust, commitment, communication and responsiveness are positively and significantly correlated with customer retention and satisfaction.Oluseyeet.al. (2014) investigated the effectiveness of customer service in the retention of GSM SIM packs using comparative analysis, and found that with effective customer service, customer loyalty and customer satisfaction and customer retention can be achieved.Agyei and Kilika (2013) investigated the relationship between service quality and customer loyalty in Kenyan mobile telecommunication industry. The study found that all the indicators of service quality (SERVQUAL) model have positive correlation with customer loyalty. Empathy has the highest influence on customer loyalty.Njane (2013) established the factors which prevent and affect customer retention in banks in Kenya using a case study of Barclays Bank of Kenya. The study found that customer retention is influenced by accuracy of transactions, delivery of services, efficiency of customer services, physical appearance of the bank and the convenience of the branch locations. Further findings indicated that customer retention in banks is also influenced by the corporate image of the banks based on the stability, familiarity and reliability. Competitive advantage of the bank through advertisements, unique and distinctive products and competitive pricing were other factors influencing customer retention.

Amin et.al. (2012) determined contributing factors to customer loyalty towards telecommunication service provider in Malaysia. Data were collected from 185 telecommunication users among university students. The findings indicated that there is a positive relationship between switching cost, trust, corporate image and perceived service quality with customer loyalty. Perceived service quality was found to be the most critical factor in affecting users' customer loyalty.Jahanshahiet.al. (2011) addressed the following questions: is there a relationship between customer service and product quality with customer satisfaction and loyalty in the context of the Indian automotive industry? If yes, how is the relationship between these four variables? Results of the study showed that there are high positive correlation between the constructs of customer service and product quality with customer 
satisfaction and loyalty. Omotayo and Joachim (2008) attempted to find the relationship between customer service and customer retention in telecommunication industry in Nigeria. This study examined the potential constructs in customer retention by investigating the chain of effects of retention from customer service, satisfaction, value and behavioural intention. The hypotheses are supported except that a higher level of customer satisfaction does not lead to customer loyalty.

\subsection{Research Gap and Contributions of the Study}

In the contemporary business settings, retention of customers has become extremely important because a majority of business organisations witnessed a visible loss of customers. This is more visible in the mobile telecommunication industry which is facing a stiff competition, making customer service to become a critical issue. After going through the literature review, it is observed that a research gap exists and there is a need to make a fresh attempt to explore the association among customer service and customer retention in the context of telecom arena. Firstly, the studies are divergent in their conception. In fact, majority of the studies (Agyei\&Kalika, 2013; Dubey \& Srivastava, 2016; Ngo \& Nguyen, 2016) have focused on the impact of service quality on customer satisfaction and loyalty. Omotayo and Joachim (2008) emphasized the relationship between customer service and customer retention, while Oluseyeet.al. (2014) focused on the effectiveness of customer service in the retention. By cons, Jahanshahiet.al. (2011) addressed the relationship between customer service and product quality with customer satisfaction and loyalty and Njane (2013) the factors affecting customer retention.

Secondly, majority of previous research studies focus on service quality instead of customer service(Agyei\&Kalika, 2013; Dubey \& Srivastava, 2016; Ngo \& Nguyen, 2016; Izogo, 2016; Boora, 2017; Hafez \&Akther, 2017; Rizomyliotiset.al., 2018; Chee, 2019). Just few studies emphasize on customer service (Omotayo\& Joachim, 2008; Jahanshahi et.al., 2011; Oluseyeet.al., 2014). If the two concepts seem to be similar in the service industry, it is not the case. In fact customer service can be considered as a sub-construct of service quality as depicted in the conceptual framework of Chee (2019). Also, authors who worked on customer service did not emphasize on its potential constructs. In the present study, in addition to studying the overall customer service effect, an endeavourhas been made to identify the constructs of customer service through the use of Principal Component Analysis and also determine their effect on customer retention. As per the dependent variable, it should be noted that in majority of previous works reviewed, the concepts of customer loyalty and customer retention are globally used to express the same thing. But, it should not be considered so because customer loyalty is based on customer perspective while customer retention is more oriented towards companies' efforts. We think with the intensification of competition and the costs attached to customers' attrition, it is important to put emphasis on customer retention because companies have to design strategies to reduce customers' attrition. In addition, customer loyalty is used as a proxy of customer retention.

Finally, most of the study were conducted in other contexts such as Ethiopia, Nigeria, Kenya, Malaysia, India, etc. and none of these studies was from Cameroon especially South-West Region. The present research study is an attempt to examine the effect of customer service on customer retention of a State owned telecommunication company in a crisis zone. Findings of the study are very useful for Telecom operators in designing their customer retention strategies.

\section{MeThOdOLOGY}

\subsection{Data}

Data used in this study were collected through questionnaire from 90 users of Camtel South-West services for at least three years. This was in order to integrate in the sample customers that have been in relation with Camtel and can be considered as loyal to an extent. Due to the ongoing crisis in South-West and North-West regions of Cameroon, the convenience sampling technique was used to select different respondents. More than half of the respondents $48(53.3 \%)$ were males while $42(46.7 \%)$ of them were females. In terms of longevity in using Camtel services, $63.3 \%$ have been 
using Camtel services for about 3-5 years, while $26.7 \%$ of have been customers of Camtel for more than 10 years and $10 \%$ had been Camtel customers for about 6-10 years.

\subsection{Measures}

\subsubsection{Customer service}

In this study, customer service was measured through constructs obtained from a questionnaire, where respondents were required to indicate the extent to which they agree with some crucial aspects of customer service using a 5 points Likert scale ranging from "strongly disagree" to "strongly agree". Some of the aspects considered are the use of a live person to answer call; the realisation of promises on time; the delivery of service on time; the complaint management; the provision of information; the staff behaviours and attitudes, etc. 15 items were used. These items were tested for their validity and reliability. The validity analysis was conducted to determine if the data met the Kaiser Meyer-Olkin index of Sampling adequacy (KMO), Bartlett's Test of Sphericity and significance value. Globally, a factor analysis was applied to the 15 items of customer service measure using Principal Components Analysis (PCA) with Varimax rotation so as to determine the dimensions (or constructs) involved in that concept. The four factors identified explained $61.466 \%$ of the total variance (See Appendix 1 and Appendix 2). Overall results showed that KMO measure of sampling adequacy was 0.805 which is above the cut-off point (0.70) suggested by Field (2011), and the Bartlett's Test of Sphericity classified the data as adequate for analysis $\left(\lambda^{2}(105)=501.584 ; p<.000\right)$. Both Bartlett's test of Sphericity and measure of sampling adequacy (MSA) ensured that the pre-requisites of factor analysis were met.

Table1. KMO Index and Bartlett's Test

\begin{tabular}{|l|l|l|}
\hline \multicolumn{2}{|l|}{ Kaiser-Meyer-Olkin index of sampling adequacy. } & .805 \\
\hline \multirow{3}{*}{ Bartlett's Test of sphericity } & approx Chi-square. & 501.584 \\
\cline { 2 - 3 } & Df & 105 \\
\cline { 2 - 3 } & Sig & .000 \\
\hline
\end{tabular}

Meanwhile, the Cronbach's alpha coefficient was used as the reliability measure. The constructs extracted from the factor analysis were at satisfactory level reliability as the coefficients were all greater than 0.60 (Hair et.al., 2006). Information about the reliability test results are found in the table below.

Table2. Reliability Results of independent variables

\begin{tabular}{|l|l|l|}
\hline Extracted dimensions & $\mathrm{N}^{\circ}$ of item & Alpha of Cronbach \\
\hline Complaints Management & 4 & 0.697 \\
\hline Communication Management & 5 & 0.789 \\
\hline Promises Management & 3 & 0.655 \\
\hline Staff Attitudes & 3 & 0.729 \\
\hline Overall Customer Service & 15 & 0.860 \\
\hline
\end{tabular}

\subsubsection{Customer Retention}

Customer retention was measured through a composite index representing the mean of 13 questions in which respondents were also required to provide the extent to which they agree with some crucial aspects of customer retention using a 5 points Likert scale ranging from "strongly disagree" to "strongly agree". Some of the aspects considered are the satisfaction derived as regards to the total service rendered by Camtel South-West, the renewal of purchases of services rendered by Camtel South-West, the dependence on Camtel services for both internet and calls, the intention to change the Telecom provider, the intention to switch to another Telecom provider, etc. The reliability Test through alpha of Cronbach is satisfactory since alpha of Cronbach is 0.716 .

\subsubsection{Data Analysis Method}

An Ordinary Least Square (OLS) regression is applied to ascertain the effect of the customer service constructs (or dimensions) extracted from factor analysis and the overall customer service on customer retention.

The following models were estimated: 
Customer Service as a Tool for an Effective Customer Retention in Camtel South-West Region of Cameroon: An Analysis from Customer's View

\section{Model One: Constructs of Customer Service Model}

$C R=\alpha+\beta_{1} C O M P M G T+\beta_{2} C O M M G T+\beta_{3} P R O M G T+\beta_{4} S T A F A T T I+\varepsilon$

Where

$\mathrm{CR}=$ Customer Retention

COMPMGT $=$ Complaints management

COMMGT $=$ Communication management

PROMGT $=$ Promises management

STAFATTI $=$ Staff attitudes

$\alpha=$ constant

$\varepsilon=$ error term

$\beta_{i}=$ standardized coefficients

\section{Model Two: Overall Customer Service Model}

$C R=\alpha+\beta_{1} O C S+\varepsilon$

with

$\mathrm{CR}=$ Customer Retention

OCS $=$ Overall Customer Service

$\alpha=$ constant

$\varepsilon=$ error term

$\beta_{1}=$ standardized coefficient

In analyzing the results, some validation techniques were used such as; the R-Square values, F-Ratio, T-Statistics and the P-Value. These measures help to find out that the best and accurate estimated coefficient are joint. R-Square shows the percentage change of the dependent variable brought about by a joint variation of the explanatory variables specified in the models. The F-Ratio is used to test for the overall significance of all the parameters estimated. The P-Value shows the extent to which the estimated coefficient is reliable. The T-Statistics and the Standard deviation are used to justify whether the coefficient of the estimated parameter are statistically significant given the degree of freedom. The significance of variable was observed at $90 \%$ confidence level whereby, variables with a 'p' value of 0.10 and below will be deem significant.

\section{FINDINGS AND DISCUSSION}

Table 3 below presents the OLS results of the two regression models (Model 1 and Model 2).

Table3. OLS Results

\begin{tabular}{|c|c|c|c|c|c|c|}
\hline \multirow[t]{2}{*}{ Independent variables } & \multicolumn{3}{|c|}{ MODEL 1} & \multicolumn{3}{|c|}{ MODEL 2} \\
\hline & Beta & $\mathrm{T}$ & sig & Beta & $\mathrm{T}$ & sig \\
\hline Complaints Management & .088 & .800 & .426 & & & \\
\hline Communication Management & $.198 *$ & 1.730 & .087 & & & \\
\hline Promises Management & .172 & 1.562 & .122 & & & \\
\hline Staff Attitudes & $.256 * *$ & 2.341 & .022 & & & \\
\hline Overallcustomer service & & & & $.544 * * *$ & 6.086 & .000 \\
\hline (Constant) & & 7.092 & .000 & & 7.412 & .000 \\
\hline $\mathrm{R}^{2}$ & \multicolumn{3}{|l|}{.307} & \multicolumn{3}{|l|}{.296} \\
\hline Adjusted $\mathrm{R}^{2}$ & \multicolumn{3}{|l|}{.275} & \multicolumn{3}{|l|}{.288} \\
\hline Fisher & \multicolumn{3}{|l|}{9.433} & \multicolumn{3}{|l|}{37.039} \\
\hline Sig. & \multicolumn{3}{|l|}{$.000^{\mathrm{b}}$} & \multicolumn{3}{|l|}{$.000^{\mathrm{b}}$} \\
\hline
\end{tabular}

Model one: 
The value of R-squared is 0.307 implying that $30.7 \%$ variation of customer retention is accounted for by the joint variation of the customer service dimensions (communication management, complaints management, staff attitudes and promises management) of Camtel South-West whereas of that $63.4 \%$ variation in customer retention is accounted for by other factors. The F-test which examined the overall validity of the model, indicated that the model is significant at $1 \%$, that is, $(\mathrm{F}=9.433, \mathrm{P}=.000)$, this implied that our results are valid and can be used for policy changes in Camtel South-West. Globally, there is a clear assurance that the four constructs of customer service used in the model are able to explain customer retention in Camtel South-West. This assumption is partially confirmed by the results obtained since just two out of the four independent variables' coefficients are significant. The constant term in this study represents those variables that have not been mentioned in the model but also affect the level of customer retention in Camtel South-West. Here, the constant term was positive; that is, 7.092. This shows that the other variables not included on this model do influence customer retention positively. Thus, for any measure to improve customer retention such variables not included should also be taken into account.

The study reveals that communication management has a positive and significant effect on customer retention of Camtel South-West. The coefficient of communication management is 0.198. This implied that a $1 \%$ variation especially increase in CamtelSouth-West's communication management would lead to $0.198 \%$ increase customer retention. Testing for significance, the $\mathrm{P}$ value was 0.087 which is less than $10 \%$, thus implying that the test is significant. We conclude that communication management dimension of customer service has a positive significant effect on customer retention in Camtel South-West. The implication of this finding is that the more the regular interaction with customers in a warm way, the greater chance that customers are retained in the subsequent services provided. Communication management appears therefore as vital for the successful maintenance of customers' relationship as asserted by Ahmad and Buttle (2002). Globally, when customers perceive friendship, familiarity and dipper concern in the communication with staff of Camtel, they are satisfied and therefore committed in maintaining a good relation with Camtel South-West. Also, when communication is properly manage by the organisation, the desired effects described by Kotler (1992) will surely be obtained. Kotler (1992) sees marketing communication as a process of transmitting information to customers to stimulate buying behaviors, attract their patronage and keep them posted on further information about the products and services of the organization. Communication explains the exchanging of ideas, feelings and impressions between a customer and a seller in a warm and personal way. This finding aligns with the study of Akintunde and Akaighe (2016) who showed a significant positive correlation between communication and customer retention in Nigeria Banking Industry. It also comfort the findings of Olotu, Maclayton and Opara (2010) that point out the need to efficiently and effectively practice communication to improve the level of customer retention.

The study also revealed that staff attitudes is a lever for the improvement of customer retention in Camtel South-West. The coefficient of staff attitude is 0.256 indicating that staff attitude dimension of customer service has a positive effect on customer retention in Camtel South-West. This infers that a $1 \%$ change in staff attitudes would lead to $0.256 \%$ increase in customer retention in Camtel SouthWest. Considering $\mathrm{P}<0.05$, the study conclude that staff attitudes significantly affects customer retention in Camtel South-West. Globally, with the high degree of customer contact in service organisations, staff attitudes in terms of courtesy, friendliness, helpfulness, focus on customer satisfaction, etc. are very important in establishing long-term relationships with customers. In fact, service contact should be a positive experience for the customers and to ensure that staff attitudes are of a great importance. When staff behaviours are well perceived by customers, the desired to repeat purchase or to advise others to purchase from your service provider increases. In addition, customer retention starting when an organisation has the first contact with the client, and continuing throughout the lifetime, staff play a significant role on the whole process. Courteous, friendly, helpful, customerminded staff are appropriate in providing a certain satisfaction that can keep customer for long in a transaction relationship.

In addition, promises management has no significant effect on customer retention in Camtel SouthWest region despite its positive sign. According to Jobber (2007), keeping the promises given to the customer is a vital element for maintaining the service relationship. Thus, this means that promises given to the customer should be initially realistic and those promises should be kept by enabling staff 
to deliver the service on promises made. These promises can be given to the customers through normal marketing communication channels like advertising, pro-motion and selling or stated in the company values. Therefore, Jobber (2007) states that "it is important not to over-promise with marketing communications or the result will be disappointment, and consequently customer dissatisfaction and defection". The moment of truth of keeping promises happens in the interaction between the company and the company, especially in the critical situations. The way how these moments of truth are handled effect a great deal to the strength of the customer relationship and therefore to the length of the relationship (Jobber, 2007; Storbacka\&Lehtinen, 2002).

Findings also show that complaints management does not significantly affect customer retention. This result is contrary to our expectations and the outcomes of other studies in the field of customer retention such as that of Stauss andSchoeler(2004), Boshoff (2005) and Oh (2006). These studies provided strong empirical evidence to support the positive significant impact of effective complaintshandling on customer's retention. It can be explained by the defection in complaints management by Camtel (see Appendix 3 and Appendix 4). The management of Camtel has not taken complaint management efforts as investments which help to retain customers and protect long-term stream of profit as posit by Lovelock andWirtz (2011). Some relevant policies of complaints management such as apologizing, excusing, material compensation, redoing core service right at the second try correcting what went wrong, are not too effective in Camtel South-West.

\section{Model two}

Results on the effect of overall customer service on customer retention recorded fundamental confirmation that customer service in Camtel South-West explain client retention and maintenance of long term relationship with the company. The R-squared value is 0.296 implying that $29.6 \%$ variation of customer retention is accounted for by the variation of the overall customer service of Camtel South-West whereas of that $70.4 \%$ variation in customer retention is accounted for by other factors. The F-test which examined the overall validity of the model, indicated that the model is significant at $1 \%$, that is, $(\mathrm{F}=37.039, \mathrm{P}=.000)$, this implied that our results are valid and can be used for policy changes in Camtel South-West.

These findings can be explained by the fact that despite the challenging competitive environment and complaints of customers about Camtel services, these five last years Camtel has seriously invested in modern equipment and offered to its customers a set of products and services in order to satisfy their needs. These findings are in line with the findings of Dubey and Srivastava (2016), Ngo and Nguyen (2016), Omotayo and Joachim (2008), Oluseye et.al. (2014), Agyei and Malika (2013) and Njane (2014) who demonstrated that customer service positively affects customer loyalty or customer retention.

\section{CONCLUSiON}

The purpose of this study was to analyze the effect of customer service on customer retention in CamtelFako South-West Region. The findings revealed that overall customer service is an important determinant of customer retention in Camtel, and communication management and staff attitudes are the constructs of customer service that are more important and significant in retaining customer. Based on these findings, the study recommends that the management of Camtel South-West should endeavour to upgrade the customer service and be responsive towards customers by being attentive. Management of Camtel South-West should offer great service, be quick to resolve issues, keep in touch, reward loyalty, thank their customers, continue to evolve their offerings with their customers' progress, etc. In order to achieve the above mentioned, three main steps should be taken by the management of Camtel South-West. Firstly, the management should focus on customers by engaging in Customer Relationship Management (CRM) approach. Secondly, the management should train its staff to be responsive. Thirdly, the management should develop a good information system that will allow customer to be aware of all about Camtel South-West offers and handling complaints.Besides, the above recommendations, the study also recommended that Camtel hire sales force groups that will be in charge of sensitizing potential and actual customers about the products and services offered by Camtel South-West. The management should increase the sales points in order to take advantage of proximity perspective. They should provide bonuses packages and review their pricing system 
Although the results of this study provide evidence of the effect of customer service on customer retention, it presents some limitations. First, the issued conclusions are based on a limited number of customers of Camtel South-West region only. This limits the external validity of the study as the findings are limited to one institution and one region out of 10 in Cameroon. The results may not be the same results in other telecommunication companies or other sectors. Then the study is crosssectional study, which does not take into account dynamic effects one might observe with a longitudinal study. Another limitation of the study was in terms of tools of data collection and the structured of the instrument. It was discovered that most of the respondents selected neutral options which made the descriptive analysis inconclusive unlike the use of categorical data only. Also, the regression results showed the necessity to consider other variables that can affect customer retention such as customer satisfaction, company reputation, etc.

Despite these limitations, this research opens the way for further research. First, it would be worthwhile to extend the study to camtel Cameroon (study the ten regions) or other telecommunication companies or sectors (education, food, hotels, etc.). Second, it would be interesting to apply a longitudinal approach. Thirdly, the study recommended that further studies be done to establish the factors influencing customer retention in telecommunication companies like Bhatti et.al. (2016), or to investigate the mediating effect of customer psychology on the relationship between customer service and customer retention.

\section{REFERENCES}

[1] Agyei, P. M., \&Kilika, J. M. (2013). The Relationship between Service Quality and Customer Loyalty in the Kenyan Mobile Telecommunication Service Industry. European Journal of Business and Management, 5(23), 26-36.

[2] Ahmad, R., \&Buttle, F. (2002). Customer retention management: A reflection of theory and practice. Marketing Intelligence and Planning, 20(3), 149-161.

[3] Akintunde, O. A., \&Akaighe, G. O. (2016). Customer Relationship Management (CRM) and Customer Retention in Nigeria Banking Industry: A Strategic Standpoint. Journal of Marketing Development and Competitiveness, 10(2), 81-90. . Retrieved from https://www.articlegateway.com/index.php/JMDC/article /view/ 1850

[4] Amin, S. M., Ahmad, U. N. U., \& Hui, L. S. (2012). Factors Contributing to Customer Loyalty Towards Telecommunication Service Provider. Procedia - Social and Behavioral Sciences, 40, 282 - 286

[5] Banik, S., \& Sinha, P. (2020). Factors Affecting Customer Retention in Telecom Sector: A systematic review in Indian perspective. International Journal of Engineering Research and Technology, 13 (9), 2137-2152. https://dx.doi.org/10.37624/IJER T/13.9.2020.2137-2152.

[6] Bhatti, S. A., Abareshi, A., \&Pittayachawan, S. (2016). An Empirical Examination of Customer Retention in Mobile Telecommunication Services in Australia. In Proceedings of the 13th International Joint Conference on e-Business and Telecommunications (ICETE 2016), 2, 72-77. DOI: 10.5220/000595190 0720077.

[7] Boora, K. K. (2017). Perceived Service Quality and Customer Retention in Telecommunication Services: A Structural Equation Modelling Approach. Amity Journal of Marketing, 2 (1), 1-13.

[8] Boshoff, C. (2005). A re-assessment and refinement of RECOVSAT: An instrument to measure satisfaction with transaction-specific service recovery. Managing Service Quality, 15 (5), 410-425.

[9] Chee, V. S. (2019). The Relationship of Service Quality, Customer Satisfaction, Customer Loyalty and Customer Retention in Telecommunication Industry: A Conceptual Framework. International Journal of Innovation and Business Strategy (IJIBS), 12 (2), 27-35.

[10] Coelho, P. S., \&Henseler, J. (2012). Creating customer loyalty through service customization. European Journal of Marketing, 46, 331-356.

[11] Dambush N. H. (2014). The Role of Customer Relationship Marketing on Customer Retention: A case of Ethiopian Insurance Corporation in Mekelle Branch (Tigray). MBA Thesis, College of Business and Economics, Department of Management, University of Mekelle.

[12] Dubey, A., \& Srivastava, A. K. (2016). Impact of Service Quality on Customer Loyalty- A Study on Telecom Sector in India. IOSR Journal of Business and Management (IOSR-JBM), 18 (2), 45-55. DOI: $10.9790 / 487 \mathrm{X}-18214555$. 
[13] Fluss, D. (2010). Customer Retention is a priority for Mobile Phone Providers. Available: wwwgem.org/eng/content_details.jsp?contentid=2317\&subjected $=107$.

[14] Hafez, Md., \&Akther, N. (2017). Determinants of Customer Loyalty in Mobile Telecommunication Industry in Bangladesh. Global Journal of Management and Business Research, 17 (1), 140-148.

[15] Hair, J.F. Jr., Black, W.C., Babin, B. J., Anderson, R.E., \& Tatham, R.L. (2009). Multivariate Data Analysis, $7^{\text {th }}$ ed., NJ, Pearson Prentice Hall.

[16] Hau, N. L., \& Ngo, L. V. (2012). Relationship marketing in Vietnam: An empirical study. Asia Pacific Journal of Marketing and Logistics, 24(2), 222-235. DOI: 10.1108/13555851211218039.

[17] Hossain, Md. A., Chowdhury, Md. R., \& Jahan, N. (2017). Customer Retention and Telecommunication Services in Bangladesh. International Journal of Asian Social Science, 7 (11), 921-930.

[18] Izogo, E. E. (2016). Customer Loyalty in Telecom Service Sector: The Role of Service Quality and Customer Commitment. The TQM Journal, 29 (1), 1-20.

[19] Jahanshahi, A. A., Gashti, M. A. H., Mirdamadi, S. A., Nawaser, K., \&Khaksar, S. M. S. (2011). Study the Effects of Customer Service and Product Quality on Customer Satisfaction and Loyalty. International Journal of Humanities and Social Science, 1(7), 253-260.

[20] Komunda, M., \&Osarenkhoe, A. (2012). Remedy or cure for service failure?: Effects of service recovery on customer satisfaction and loyalty. Business Process Management Journal, 18 (1), 82-103.

[21] Leal, R. P., \& Pereira, Z. L. (2003). Service recovery at a financial institution. International Journal of Quality \& Reliability Management, 20 (6), 646-663.

[22] Lovelock, C. H. \&Wirtz, J. (2011). Services marketing: people, technology, strategy, 7th ed, Prentice Hall, Boston.

[23] Lucas, R (2005). Customer Service, 3rd edition, New York: McGraw-Hill/Irwin Publishing House.

[24] McCrory, B. (2013). Customer Retention through the Equal Incorporation of Continuous Improvement (CI), Culture and Customer Service. DBA Thesis, Edinburgh Napier University.

[25] Menon, K., \& O’Connor, A. (2007). Building Customers' Affective Commitment towards Retail Banks: The Role of CRM in each moment of Truth. Journal of Financial Services Marketing, 12 (2), 157-168.

[26] Molapo, M. E., \&Mukwada, G. (2011). The Impact of Customer Retention Strategies in the South African Cellular Industry: The Case of the Eastern Free State. International Journal of Business, Humanities and Technology, 1 (2), 52-60.

[27] Mostert, P.G., Meyer, D, \&Rensburg, L.R.J. (2009). The influence of service failure and service recovery on airline passnger's relationships with domestic airline: an exploratory study. South African Business Review, 13 (2), 87-98.

[28] Narteh, B. (2013). Key determinant factors for retail bank switching in Ghana. International Journal of Emerging Markets, 8 (4), 409-427.

[29] Ngo, V. M., \& Nguyen, H. H. (2016). The Relationship between Service Quality, Customer Satisfaction and Customer Loyalty: An Investigation in Vietnamese Retail Banking Sector. Journal of Competitiveness, 8(2), 103-116. DOI: 10.7441/joc.2016.02.08

[30] Njane, J. G. (2013). An Investigation of Factors Affecting Customer Retention in Barclays Banks of Kenya. MBA project, School of Business, University of Nairobi.

[31] Oh, D. (2006). Complaining intentions and their relationships to complaining behavior of academic library users in South Korea. Library Management, 27 (3), 168-189.

[32] Oluseye, O. O., Odunayo, S., Adeniyi, S., \&Borishade, T. T. (2014). Evaluation of Customer Service and Retention; A comparative Analysis of Telecommunication Service Providers. European Journal of Business and Social Sciences, 3 (8), 273-288.

[33] Oluseye, O. O., Odunayo, S., Adeniyi, S., \&Borishade, T. T. (2014). Evaluation of Customer Service and Retention; A comparative Analysis of Telecommunication Service Providers. European Journal of Business and Social Sciences, 3 (8), 273-288.

[34] Omotayo, O., \& Joachim, A. A. (2008). Customer service in the retention of mobile phone users in Nigeria. African Journal of Business Management, 2(2), 26-31. Available online at http://www.academi cjournals.org/AJBM

[35] Otaigbe, E. E. (2018), Exploring Satisfaction and Retention Strategies for Generation Y Customers. (10811453 D.B.A.), Walden University, Ann Arbor.

[36] Parasuraman, A., Zeithaml, V. A., \& Berry, L. L. (1988). SERVQUAL: A Multiple-Item Scale for Measuring Customer Perceptions of Service Quality. Journal of Retailing, 64, 12-23. 
Customer Service as a Tool for an Effective Customer Retention in Camtel South-West Region of Cameroon: An Analysis from Customer's View

[37] Preikschas, M. W., Cabanelas, P., Rudiger, K., \&Lampon, J. F. (2017). Value cocreation, dynamic capabilities and customer retention in industrial markets. Journal of Business and Industrial Marketing, 32, 409-420.

[38] Ramakrishnan, K. (2006). Customer retention: the key to business performance (online). Available: http://www.estrategicmarketing.com/smNov-Dec2/art11.html

[39] Rizomyliotis, I., Konstantoulaki, K., Kaminakis, K., Giovanis, A., \&Papastathopoulos, A. (2018). Antecedents of Customer Loyalty in the Mobile Telecommunication Market. A Cross-cultural Investigation. Academy of Marketing Studies Journal, 22 (4), 1-10.

[40] Stauss, B., \&Schoeler, A. (2004). Complaint management profitability: what do complaint managers know?.Managing Service Quality, 14 (2), 147-156.

[41] Storbacka, K., \&Lehtinen, J. R. (2001). Customer Relationship Management: Creating Competitive Advantage through Win-win Relationship Strategies. New York, McGraw Hill.

[42] Winer, R. (2001). A Framework for Customer Relationship Management. California Management Review, 43 (4), 89-105.

[43] Zeithaml, V. A., \&Bitner, M. J. (2003). Services Marketing: Integrating Customer Focus Across the Firm. Boston: McGraw-Hill Irwin. Relationship between Types of Problems and Customer Responses". Canadian Journal of Administrative Sciences, 13 (3): 264-276.

\section{APPENDICES}

\section{Appendix 1}

\begin{tabular}{|c|c|c|c|c|c|c|c|c|c|}
\hline \multicolumn{10}{|c|}{ Total Variance Explained } \\
\hline \multirow[b]{2}{*}{$\begin{array}{l}\text { Compo } \\
\text { nent }\end{array}$} & \multicolumn{3}{|c|}{ Initial Eigenvalues } & \multicolumn{3}{|c|}{$\begin{array}{l}\text { Extraction Sums of Squared } \\
\text { Loadings }\end{array}$} & \multicolumn{3}{|c|}{ Rotation Sums of Squared Loadings } \\
\hline & Total & $\begin{array}{l}\% \\
\text { Variance }\end{array}$ & of Cumulative & Total & $\begin{array}{l}\% \\
\text { Variance }\end{array}$ & Cumulative & Total & $\begin{array}{l}\% \\
\text { Variance }\end{array}$ & of Cumulative \\
\hline 1 & 5.291 & 35.273 & 35.273 & 5.291 & 35.273 & 35.273 & 2.698 & 17.984 & 17.984 \\
\hline 2 & 1.603 & 10.687 & 45.961 & 1.603 & 10.687 & 45.961 & 2.657 & 17.714 & 35.698 \\
\hline 3 & 1.187 & 7.915 & 53.875 & 1.187 & 7.915 & 53.875 & 2.002 & 13.345 & 49.043 \\
\hline 4 & 1.139 & 7.590 & 61.466 & 1.139 & 7.590 & 61.466 & 1.863 & 12.422 & 61.466 \\
\hline 5 & .952 & 6.347 & 67.812 & & & & & & \\
\hline 6 & .883 & 5.886 & 73.698 & & & & & & \\
\hline 7 & .744 & 4.959 & 78.658 & & & & & & \\
\hline 8 & .718 & 4.788 & 83.446 & & & & & & \\
\hline 9 & .541 & 3.604 & 87.050 & & & & & & \\
\hline 10 & .476 & 3.175 & 90.225 & & & & & & \\
\hline 11 & .429 & 2.858 & 93.082 & & & & & & \\
\hline 12 & .310 & 2.069 & 95.151 & & & & & & \\
\hline 13 & .290 & 1.931 & 97.082 & & & & & & \\
\hline 14 & .248 & 1.652 & 98.734 & & & & & & \\
\hline 15 & .190 & 1.266 & 100.000 & & & & & & \\
\hline
\end{tabular}

\section{Appexdix 2}

\begin{tabular}{|c|c|c|c|c|}
\hline \multicolumn{5}{|l|}{ Rotated Component Matrix $^{\mathrm{a}}$} \\
\hline & \multicolumn{4}{|c|}{ Component } \\
\hline & 1 & 2 & 3 & 4 \\
\hline $\begin{array}{l}\text { Any time you try to call Camtel South-West phone. a live person usually } \\
\text { answer to your call }\end{array}$ & $y .063$ & .550 & .098 & -.242 \\
\hline All the promises make by Camtel South-West are always realized on time & .135 & .107 & .793 & .055 \\
\hline The delivery of service in Camtel South-West is make on promised time & .281 & .199 & .634 & .057 \\
\hline Camtel stick to their timing promises & -.076 & .330 & .661 & .289 \\
\hline $\begin{array}{l}\text { Camtel staff usually listen to you talking and provide appropriate responses to } \\
\text { you }\end{array}$ & .045 & .833 & .085 & .091 \\
\hline CAMTEL South-West properly dealt with complaint given by customers & .666 & .263 & .156 & .173 \\
\hline CAMTEL South-West assigns adequate time to respond to my complaints & .760 & -.078 & .311 & -.039 \\
\hline CAMTEL South-West apologizes whenever a complaint is made & .579 & .322 & .256 & -.063 \\
\hline Camtel South-West provides information about handling complaint & .657 & .180 & -.175 & .130 \\
\hline
\end{tabular}


Customer Service as a Tool for an Effective Customer Retention in Camtel South-West Region of Cameroon: An Analysis from Customer's View

\begin{tabular}{|c|c|c|c|c|}
\hline $\begin{array}{l}\text { Camtel South-West staff are friendly. helpful and always keep their eyes on- } \\
\text { customer satisfaction }\end{array}$ & -.020 & .114 & .136 & .827 \\
\hline The staff of Camtel South-West is courteous and knowledgeable & .546 & .106 & .035 & .602 \\
\hline The staff-customer interaction is well done in Camtel South-West & .563 & .061 & 285 & .568 \\
\hline The staff of Camtel SW always lead you to the service you request for & 192 & .556 & 249 & .201 \\
\hline The staff of Camtel SW is well train in attaining customers & .231 & .618 & .340 & .372 \\
\hline $\begin{array}{l}\text { Camtel SW usually provide additional information on how to use the service. } \\
\text { provided }\end{array}$ & .310 & .756 & .141 & .327 \\
\hline \multicolumn{5}{|l|}{$\begin{array}{l}\text { Extraction Method: Principal Component Analysis. } \\
\text { Rotation Method: Varimax with Kaiser Normalization. }\end{array}$} \\
\hline
\end{tabular}

Appendix3. Descriptive statistics

\begin{tabular}{|l|l|l|l|}
\hline & N & Mean & Std. Deviation \\
\hline Overall Customer Service & 90 & 2.9007 & .64576 \\
\hline Customer Retention & 90 & 2.9863 & .54351 \\
\hline Complaints Management & 90 & 2.6056 & .82787 \\
\hline Communication Management & 90 & 3.0267 & .80403 \\
\hline Promises Management & 90 & 3.1630 & .80300 \\
\hline Staff Attitudes & 90 & 2.8222 & .93242 \\
\hline Valid N (listwise) & 90 & & \\
\hline
\end{tabular}

Appendix4. Complaint Management Descriptive Results.

\begin{tabular}{|c|c|c|c|c|}
\hline & Frequency & Pourcentage & ValidPourcentage & \begin{tabular}{|l} 
Cumulative \\
Pourcentage
\end{tabular} \\
\hline \multicolumn{5}{|c|}{ Camtel South-West properly dealt with complaint given by customers } \\
\hline StronglyDisagree & 10 & 11.1 & 11.1 & 11.1 \\
\hline Disagree & 10 & 11.1 & 11.1 & 22.2 \\
\hline Neutral & 39 & 43.3 & 43.3 & 65.6 \\
\hline Agree & 23 & 25.6 & 25.6 & 91.1 \\
\hline StronglyAgree & 8 & 8.9 & 8.9 & 100.0 \\
\hline Total & 90 & 100.0 & 100.0 & \\
\hline \multicolumn{5}{|c|}{ Camtel South-West assigns adequate time to respond to my complaints } \\
\hline StronglyDisagree & 11 & 12.2 & 12.2 & 12.2 \\
\hline Disagree & 13 & 14.4 & 14.4 & 26.7 \\
\hline Neutral & 36 & 40.0 & 40.0 & 66.7 \\
\hline Agree & 17 & 18.9 & 18.9 & 85.6 \\
\hline StronglyAgree & 13 & 14.4 & 14.4 & 100.0 \\
\hline Total & 90 & 100.0 & 100.0 & \\
\hline \multicolumn{5}{|c|}{ Camtel South-West apologizes whenever a complaint is made } \\
\hline StronglyDisagree & 11 & 12.2 & 12.2 & 12.2 \\
\hline Disagree & 18 & 20.0 & 20.0 & 32.2 \\
\hline Neutral & 34 & 37.8 & 37.8 & 70.0 \\
\hline Agree & 21 & 23.3 & 23.3 & 93.3 \\
\hline StronglyAgree & 6 & 6.7 & 6.7 & 100.0 \\
\hline Total & 90 & 100.0 & 100.0 & \\
\hline \multicolumn{5}{|c|}{ Camtel South-West provides information about handling complaint } \\
\hline StronglyDisagree & 17 & 18.9 & 18.9 & 18.9 \\
\hline |Disagree & 28 & 31.1 & 31.1 & 50.0 \\
\hline Neutral & 27 & 30.0 & 30.0 & 80.0 \\
\hline Agree & 12 & 13.3 & 13.3 & 93.3 \\
\hline StronglyAgree & 6 & 6.7 & 6.7 & 100.0 \\
\hline Total & 90 & 100.0 & 100.0 & \\
\hline
\end{tabular}

\section{AUTHOR'S BIOGRAPHY}

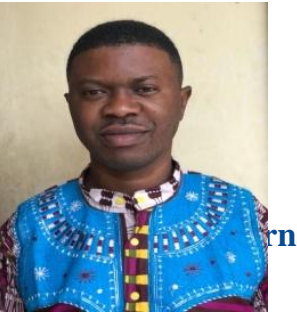

Dr. NWAHANYE Emmanuel, is a Ph.D holder from the University of Yaoundé II-Soa. He is a Senior Lecturer of Management at the University of Buea, Cameroon. His main area of interest is Human Resource Management, but also 
Customer Service as a Tool for an Effective Customer Retention in Camtel South-West Region of Cameroon: An Analysis from Customer's View

researches on management-oriented fields like Marketing. His current project is to build a strong research team from postgraduate students.

Citation: Dr. Nwahanye Emmanuel. "Customer Service as a Tool for an Effective Customer Retention in Camtel South-West Region of Cameroon: An Analysis from Customer's View" International Journal of Managerial Studies and Research (IJMSR), vol 9, no. 2, 2021, pp. 7-19. doi: https://doi.org/10.20431/23490349.0903002.

Copyright: (0) 2021 Authors. This is an open-access article distributed under the terms of the Creative Commons Attribution License, which permits unrestricted use, distribution, and reproduction in any medium, provided the original author and source are credited. 